\author{
Mikołaj Bednarek* \\ ORCID: 0000000215242892 \\ Uniwersytet Wrocławski
}

https://doi.org/10.19195/1733-5779.31.7

\title{
Kryzys praworządności w Polsce i na Węgrzech. Spojrzenie teoretycznoprawne
}

\author{
JEL Classification: K38, K30, K39
}

Słowa kluczowe: praworządność, Polska, Węgry, Europa Środkowo-Wschodnia, kryzys

Keywords: rule of law, Poland, Hungary, CEE, crisis

\begin{abstract}
Abstrakt: Artykuł analizuje kryzys praworządności występujący w Polsce i na Węgrzech. Kompleksowa analiza historii oraz społeczeństwa upatruje w nich źródło kryzysu. Artykuł przedstawia ogólne spojrzenie na teorie praworządności, ze szczególnym naciskiem na relacje pomiędzy jego elementami. Artykuł ma na celu pokazanie, że myśl polskiego i węgierskiego społeczeństwa jest odmienna od zachodnich wartości. Ta trudność powoduje, że bycie państwem praworządnym jest niemożliwe. Rozwiązania prawne państw Europy Zachodniej w połączeniu z wartościami i dziedzicem historycznym Polski i Węgier nie działają prawidłowo. Powodem jest tylko częściowa implementacja zachodniej teorii praworządności i brak wewnętrznych wartości prawa, które nie doprowadziły do rządów prawa w praktyce.
\end{abstract}

\section{The rule of law crisis in Poland and Hungary. A theoretical point of view}

Abstract: The article analyzes the issue of the rule of law crisis in Poland and Hungary. A comprehensive analysis of history and societies identify the causes of the crisis. It involves a general presentation of the rule of law theory. The article tries to show that the prevailing thought in Poland and Hungary is different to that of western European values. This difficulty makes the rule of law in the country impossible. The Western European legal system solution combined with Eastern European values and the legacy of history does not work properly, because the whole theory has not been implemented. Its practical implementation with local values has in fact not led to the rule of law.

* Opiekun naukowy (Scientific Tutor) — dr Michał Paździora 


\section{Preludium historyczne obrazujące kryzys praworządności}

Obecny rozwój prawno-polityczny całej Europy koncentruje się na integracji oraz współpracy. Widoczne jest to przede wszystkim w prawie i polityce Unii Europejskiej. Jednakże coraz częściej mówi się o kryzysie praworządności jako „kryzysie demokracji w państwach Europy Środkowo-Wschodniej”, „kryzysie migracyjnym”, „kryzysie strefy euro” oraz „Brexicie”. Daje się to zauważyć nawet $\mathrm{w}$ popularności zagadnień $\mathrm{w}$ wyszukiwarkach internetowych ${ }^{2}$. Statystyki pokazują, że w zależności od dnia popularność danej frazy jest różna, jednak zainteresowanie społeczeństwa tym tematem nie maleje, a w zależności od incydentów państw europejskich w niektórych okresach nawet jest wzmożona. Doskonale widać to na przykładzie fraz „Polexit” oraz „democracy in Poland” — można zaobserwować nagły wzrost zainteresowania w okolicach 15 grudnia 2019 roku, zaraz po nagłośnieniu przez media opinii D. Kawczyńskiego, brytyjskiego posła na temat perspektywy wystąpienia Polski z Unii Europejskiej ${ }^{3}$. Kryzys pojawił się w Europie Środkowo-Wschodniej, rozumianej jako państwa mające wspólne korzenie kulturowe oraz leżące w danym okręgu geograficznym, które w przeszłości były buforowymi socjalistycznymi republikami podlegającymi ZSRR ${ }^{4}$. Należy jednak skupić uwagę na dwóch państwach regionu, w których polityka najbardziej oddaliła się od integracji europejskiej — Polsce i Węgrzech. Wydaje się, że nieunikniony kryzys jest swoistą antytezą do integracji europejskiej, zgodnie z założeniami dialektyki heglowskiej — „każda teza zawiera już w sobie antytezę, obydwie zaś zostają zniesione w syntezie"s. Systemem w niniejszym rozważaniu jest kierunek oraz związane z nim prawa i zasady, w którym idzie cała Europa.

Teoretycznoprawny punkt widzenia wskazuje, że kryzys występuje, gdy jeden z elementów praworządności nie istnieje. Na potrzeby artykułu użyty zostanie termin „triada praworządności”, który składa się z zasady legalizmu, wewnętrznych oraz zewnętrznych wartości prawa. Jeśli brakuje jednego z elementów triady, to w państwie następuje kryzys praworządności. Przyczyn urzeczywistniających ten stan może być wiele. W przypadku Polski i Węgier jest nim kultura prawna oraz niewystarczająca edukacja w zakresie prawa społeczeństwa, umożliwiająca instrumentalizowanie prawa przez elity polityczne. Celem artykułu jest analiza terminu

${ }^{1}$ C. Leyland, Old Words, new words, EU Words: Brexit and the OED, https://public.oed.com/ blog/brexit-and-the-oed/ (dostęp: 24.05.2019).

2 https://trends.google.com/trends/explore?q=democracy\%20 crisis.

3 A. Mierzyńska, Polacy wcale nie chca Polexitu! Fatszywa sensacja po sondażu Eurobarometru, https://oko.press/polacy-wcale-nie-chca-polexitu-falszywa-sensacja-po-sondazu-eurobarometru/ (dostęp: 21.12.2019).

4 T. Stryjek, Europa Środkowa (Środkowo-Wschodnia), czyli o pochwale różnorodności i komparatystyki, „Kwartalnik Historyczny” 120, 2013, nr 4, s. 764-769.

5 E. Skokowska, Ksztattowanie się ducha absolutnego wedtug Georga Wilhelma Friedricha Hegla, https://ethnographerwrites.wordpress.com/2009/05/02/35/ (dostęp: 2.05.2009). 
„praworządność”, a przez prowadzone rozważania — wskazanie przyczyny braku praworządności w Polsce i na Węgrzech oraz ukazanie, który z elementów triady nie występuje obecnie w państwach.

Działania pogłębiające kryzys znajdują wielu zwolenników wśród społeczeństwa, co uwidacznia poparcie wśród społeczeństw państw Polski oraz Węgier, mimo licznej krytyki specjalistów. Kryzys praworządności nie pojawił się znikąd. Aby do niego doszło, muszą wystąpić pewne zmiany lub wydarzenia w danym społeczeństwie. Należy zatem, choćby w minimalnym stopniu, przeanalizować tło historyczne - przede wszystkim zwrócić uwagę na procesy, wydarzenia i zjawiska, które doprowadziły do obecnego kryzysu. Pomoże nam to zrozumieć jego istotę.

Najwidoczniejszym elementem kryzysu dla mediów światowych było dojście do władzy Viktora Orbana na Węgrzech oraz sprawowanie rządów przez Prawo i Sprawiedliwość na czele z Jarosławem Kaczyńskim w Polsce ${ }^{6}$. Momentem, który zapoczątkował kryzys na Węgrzech, jest dojście do władzy koalicji Fideszu i Chrześcijańsko-demokratycznej Partii Ludowej i zaprzysiężenie przez obecnego prezydenta na stanowisko premiera — Viktora Orbana w dniu 29 maja 2010 roku. W kolejnym roku doszło do uchwalenia nowej konstytucji oraz poważnych zmian w systemie podatkowym, które nie spotkały się z aprobatą społeczeństwa ${ }^{7}$. Następstwem tych wydarzeń był kryzys gospodarczy w państwie ${ }^{8}$. Pomimo to w 2014 roku, a także w 2018 roku, koalicja prowadzona przez Viktora Orbana zwyciężyła w wyborach. Peter Kreko podaje, że powodem takiego stanu rzeczy była bardzo mocno podzielona opozycja i zmiana sposobu myślenia społeczeństwa, spowodowana polityką oraz wystąpieniami prezydenta Węgier podczas poprzedniej kadencji ${ }^{9}$.

W Polsce kryzys przebiegał inaczej, jednakże rozpoczął się podobnie. Tym wydarzeniem było zdobycie większości mandatów przez Prawo i Sprawiedliwość w wyborach do Sejmu. Partia zwyciężyła w wolnych i demokratycznych wyborach, zdobywając większość głosów, a co za tym idzie większość miejsc w Sejmie. Partia na czele z Jarosławem Kaczyńskim rozpoczęła swoje rządy 12 listopada 2015 roku. Podczas pierwszych miesięcy rządów PiS pojawił się kryzys ustrojowy związany z Trybunałem Konstytucyjnym, a dokładniej — dotyczący narusze-

${ }^{6}$ R.D. Kelemen, Europa nie powinna poddawać się w walce o praworzadność, https://www. euractiv.pl/section/grupa-wyszehradzka/opinion/europa-nie-powinna-zaprzestac-walki-o-praworzadnosc/ (dostęp: 8.07.2019).

7 A. Morrow, Hungary stages mass protest against new constitution, https://www.pri.org/stories/2012-01-03/hungary-stages-mass-protest-against-new-constitution (dostęp: 3.01.2012).

8 J. Kaźmierczyk, D. Nowak, Czy kryzys węgierski można potraktować jako przykład kryzysu modelu gospodarki?, [w:] W poszukiwaniu nowego ładu ekonomicznego, red. A. Pollok, S. Owsiak, Warszawa 2013, s. 54.

${ }^{9}$ G. Ślubowski, Wybory na Węrzech. Skąd wziąt się sukces Viktora Orbana?, https://www. polskieradio.pl/7/1696/Artykul/2089448,Wybory-na-Wegrzech-Skad-wzial-sie-sukces-Viktora-Orbana (dostęp: 9.04.2018). 
nia niezawisłości sądów. Doszło do podwójnej nowelizacji ustawy o Trybunale Konstytucyjnym; obie zostały zaskarżone do Trybunału Konstytucyjnego. Wyroki w tej sprawie oficjalnie nie zostały opublikowane ${ }^{10}$. Wydarzenia te nie tylko wzbudziły niepokój w społeczeństwie co do legalności i praworządności, ale także wśród organizacji międzynarodowych, zwłaszcza Unii Europejskiej. Parlament Europejski 1 marca 2018 roku wydał rezolucję w kwestii uruchomienia procedury $\mathrm{z}$ artykułu 7 Traktatu o Unii Europejskiej ${ }^{11}$. Odpowiedzią na kryzys było wiele manifestacji dotyczących Trybunału Konstytucyjnego. Szacuje się, że w obronie sądów przeprowadzono protesty w ponad dwustu pięćdziesięciu miastach — nie tylko w Polsce, ale i świecie ${ }^{12}$. Najbardziej zauważalnym na świecie i dramatycznym wydarzeniem wywoływanym przez kryzysem było samospalenie Piotra Szczęsnego w ramach protestu, który stwierdził, że jedną z głównych przyczyn jego samobójstwa było „niszczenie systemu niezależnych sądów”"13.

Mimo niepokojów społecznych partia PiS ponownie wygrała wybory. Odpowiedzią na taki stan rzeczy może być mechanizm zwany polaryzacją społeczną. Kryzys praworządności jest ważnym tematem społecznym, dlatego też naturalne jest zróżnicowanie społeczeństwa $\mathrm{w}$ tej kwestii. W tym procesie społecznym zazwyczaj tworzone są dwa zupełnie odmienne światopoglądy, które konkurują z sobą, a liczba osób umiarkowanie ustosunkowanych do problemu maleje. Proces ten dezintegruje społeczeństwo ${ }^{14}$.

Wydarzenia w Polsce i na Węgrzech były jednak asumptem do dyskusji w Europie na temat bezpieczeństwa prawa oraz szacunku do niego. Narodził się konflikt wartości i niezgoda na Starym Kontynencie, który związany był nie z samym prawem, lecz modelem prowadzenia polityki wewnętrznej i zewnętrznej państw.

\section{Praworządność}

Praworządność jest głównym tematem niniejszej analizy. W związku z tym należy właściwie rozłożyć ją na mniejsze elementy, aby móc zrozumieć kryzys

10 D. Uhlig, A. Kubik, M. Wilgocki, Licznik tyka: już dwa lata bez publikacji wyroku Trybunatu Konstytucyjnego, http://sonar.wyborcza.pl/sonar/7,156422,23120979, dwa-lata-bez-publikacji-wyroku-tk-licznik.html (dostęp: 9.03.2018).

11 Rezolucja Parlamentu Europejskiego z dnia 1 marca 2018 roku w sprawie decyzji Komisji o zastosowaniu art. 7 ust. 1 TUE w związku z sytuacją w Polsce (2018/2541(RSP)).

12 Wszystkie protesty na jednej mapie. W obronie sądów spotkaliśmy się w ponad 250 miastach, http://biqdata.wyborcza.pl/biqdata/7,159116,22176137,wszystkie-protesty-na-jednej-mapie-w-obronie-sadow-spotkalismy.html (dostęp: 24.07.2017).

13 J. Chełmiński, Nie żyje Piotr S., który podpalit się pod Pałacem Kultury, https://warszawa. wyborcza.pl/warszawa/7,54420,22580825, nie-zyje-piotr-s-mezczyzna-ktory-podpalil-sie-pod-palacem.html (dostęp: 29.10.2017).

${ }_{14}$ M. Kleiber, Kleiber: Polaryzacja spoleczna zagraża gospodarce i bezpieczeństwu państwa, https://www.gazetaprawna.pl/artykuly/935034,kleiber-polaryzacja-spoleczna-zagraza-gospodarce-i-bezpieczenstwu-panstwa.html (dostęp: 11.04.2016). 
praworządności. Termin ten w szerokim znaczeniu to przestrzeganie prawa przez wszystkich adresatów norm prawnych, a w węższym — przestrzeganie ich przez organy państwowe i samorządowe ${ }^{15}$. Takie rozumienie praworządności jest nieadekwatne. Praworządność w tym znaczeniu nie obejmuje wielu czynników, takich jak obchodzenie prawa czy wtórne legalizowanie bezprawia. Postawiony jest tutaj znak równości między praworządnością a zasadą legalizmu. Dlatego, oprócz elementu legalności, należy zestawić jeszcze wewnętrzne i zewnętrzne wartości prawa, które kładą nacisk na aksjologię ${ }^{16}$ — tylko wtedy osiągniemy najpełniejsze znaczenie praworządności. Poszukiwania istoty praworządności należy zatem zacząć wśród prekursorów idei, a jej rozwinięcia — u współczesnych myślicieli.

Praworządność należy łączyć z państwem prawa; pierwszy z terminów wchodzi w skład drugiego. Znaczenie terminu państwa prawa, po niemiecku Rechtsstaat, było przeciwieństwem państwa policyjnego Polizeistaat — w kontrze do absolutyzmu. Termin powstał za myślą Immanuela Kanta:

Wolność (jako niezależność od arbitralnego przymusu ze strony innych), o ile może ona współistnieć z wolnością innego człowieka w granicach powszechnego prawa, jest owym jedynym, przyrodzonym prawem, które każdemu człowiekowi przysługuje na mocy jego człowieczeństwa ${ }^{17}$.

Drugim myślicielem kształtującym podstawy praworządności był Wilhelm von Humboldt:

Państwo powinno powstrzymać się od wszelkiej troski o rzeczywisty dorobek obywateli i nie posuwać się ani kroku dalej, aniżeli to konieczne dla zabezpieczenia przeciw sobie oraz przeciw wrogom zewnętrznym; dla żadnego innego celu państwo nie powinno ograniczać ich wolności ${ }^{18}$.

Te słowa są myślą przewodnią idei państwa prawa, a co za tym idzie zasady praworządności, wyznaczając mu cele. Staje się więc tutaj widoczne, że praworządność jest narzędziem stosowanym przez systemy do realizacji określonych celów. Należy podkreślić, że praworządność nie powstała jako stricte zasada ustroju państwa, ale jako idea ochrony wolności i niezależności jednostki przed jakimkolwiek ich naruszeniem — czy to ze strony państwa, czy innych jednostek. Jest to idea powstała w celu realizacji założeń doktryny, pamiętając przy tym, że w przypadku konfliktu tych wartości pierwszeństwo powinno mieć dobro obywateli. Odwołajmy się do myśli Wilhelma von Humboldta, który „,występował [...] jako przeciwnik nadmiernego i zbędnego mnożenia przepisów, do którego ma tendencję każda władza; zwracał także uwagę na wymóg tworzenia przepisów prostych i powszechnie zrozumiałych"19.

15 S. Kaźmierczyk, [w:] Wprowadzenie do nauk prawnych. Leksykon tematyczny, Wrocław 2016, s. 251.

16 Ibidem, s. 252.

17 M. Sobolewski, Koncepcja państwa prawnego (Rechtsstaat) w doktrynie niemieckiego liberalizmu epoki klasycznej (do 1866 r.), PiP 1980, z. 2, s. 132.

18 Ibidem.

19 K. Chojnicka, H. Olszewski, Historia doktryn politycznych i prawnych, Poznań 2004, s. 183. 
Ze względu na cele praworządności wyróżniamy dwa znaczenia: materialne oraz formalne. Podział ma charakter typologii i występuje w licznych rozważaniach sądów konstytucyjnych. Doktryna pierwotnie rozumiała praworządność bardzo wąsko, skupiając się na formalnym aspekcie, zwłaszcza jednym z jej elementów - legalizmie. Prawo powinno być przestrzegane przez wszystkich, łącznie $\mathrm{z}$ organami państwowymi ${ }^{20}$. Zasada praworządności w formalnym znaczeniu ma wiele innych elementów, które zostały wypracowane latami przez doktrynę i zaaprobowane przez judykaturę państw europejskich, będąc wewnętrznymi wartościami prawa. Elementami formalnymi praworządności są: hierarchia źródeł prawa z prymatem ustaw oraz wyłączności ustawy w określonych sprawach, konstytucja jako akt o najwyższej mocy prawnej, podział władzy, ingerencja w wolności i prawa wyłącznie na mocy ustawy, nakaz legalizmu, prawidłowa legislacja, jawność, vacatio legis, ogólność norm ${ }^{21}$, zakaz stanowienia praw sprzecznych, stanowienie praw niemożliwych do spełnienia, częste zmiany prawa, uniemożliwiające kierowanie się prawem przez jednostki, stosowanie prawa niezgodnie z przepisa$\mathrm{mi}^{22}$. Elementy te są kompatybilne $\mathrm{z}$ wartościami panującymi w społeczeństwach państw europejskich, a ich realizacja kojarzy się z porządkiem, bezpieczeństwem, zaufaniem obywateli do państwa. Są to cechy wymagane do stworzenia państwa, które umożliwia zrównoważony, społeczno-gospodarczy rozwój. Należy zauważyć, że elementy formalne praworządności to dyrektywy, które stricte odnoszą się do organów państwowych, a nie poszczególnych jednostek.

Zauważyć tutaj można, że stosując rozumienie formalne, prawo może mieć treść dowolną. Można omijać prawa podstawowe jednostek, jeżeli normy stanowione przez państwo spełnią określone warunki, ukazując państwo jako podmiot realizujący praworządność ${ }^{23}$. Do takiego rozumienia praworządności przyczynił się Lon Luvois Fuller, pisząc o prawie: „przedsięwzięcie polegające na podporządkowaniu ludzkich zachowań określonym regułom"24. Zasady praworządności są zatem „wewnętrzną moralnością", ich łamanie narusza istotę prawa. Elementy formalne praworządności kreują ramy, w jakich prawo ma być pisane oraz stosowane, aby były prawem. Słusznie stwierdza Joseph Raz, pisząc o prawie: „musi mieć taką postać, że mogą oni (rząd) stwierdzić, czym prawo jest, i działać na jego podstawie"25. Elementy formalne praworządności są tak ukształtowane, aby prawo było ono jawne, zrozumiałe i stabilne ${ }^{26}$. Głównym elementem praworządności jest

20 L. Garlicki, Prawo konstytucyjne. Zarys wykładu, Warszawa 2016, s. 76.

21 Orzeczenie TK z dnia 8 maja 1990 roku, K 1/90, OTK 1990, nr 1, poz. 2.

22 T. Chauvin, Przypadki króla Rexa - koncepcja wewnętrznej moralności prawa Lona Luvois Fullera, [w:] „Edukacja prawnicza” 2013, nr 4 (142), s. 10.

23 T. Pietrzykowski, Ujarzmianie Lewiatana. Szkice o idei rządów prawa, Katowice 2014, s. 102.

${ }^{24}$ L.L. Fuller, Moralność prawa, przeł. S. Amsterdamski, Warszawa 2004, s. 82.

25 J. Raz, Autorytet prawa, przeł. P. Maciejko, Warszawa 2001, s. 213-214.

26 T. Pietrzykowski, op. cit., s. 107. 
zasada prawidłowej legislacji, ponieważ jest ona najbardziej istotnym elementem dla jednostek, a jej łamanie prowadzi do zamiany prawa w bezprawie, ponieważ jej elementy są filarami, na których opiera się istota prawa. W skład elementów prawidłowej legislacji wchodzą: stabilność prawa, zakaz retroaktywności, jasność i określoność przepisów ${ }^{27}$. Stabilność prawa jest istotna, jeżeli weźmiemy pod uwagę nie tylko kwestie aksjologiczne, ale także ekonomiczne. Zdaniem T. Pietrzykowskiego ,prawo nieustannie zmieniane nie tylko staje się dla obywateli i organów państwa nieczytelne i trudne do stosowania, lecz także znacząco ogranicza możliwość podejmowanie przez nich przedsięwzięć długofalowych, obliczonych na odległe w czasie efekty"28. Jest to sytuacja iście niekomfortowa; powoduje, że prawo staje się czynnikiem opóźniającym rozwój i niszczącym bezpieczeństwo w społeczeństwie. Dodatkowo, istotną dla stabilności prawa instytucją jest vacatio legis. Instytucja ta to niezbędny warunek, bez którego adresaci (nieważne, czy będą to podmioty prywatne, czy podmioty publiczne) nie będą mieli czasu na zaznajomienie się z nowymi normami prawnymi ${ }^{29}$. Zakaz retroaktywności jest elementem dopełniającym stabilność prawa. Złamanie go doprowadza do zmiany oceny prawnej sytuacji, która miała miejsce w przeszłości. Nie jest on bezwzględny, ponieważ występują odstępstwa od tej reguły, podyktowane względami słuszności ${ }^{30}$. Takimi względami jest dobro jednostek: lepsze wynagrodzenie, łagodniejsza kara lub całkowicie jej zniesienie ${ }^{31}$. Jednoznaczność prawa natomiast to element, który możemy podzielić na dwie części. Subiektywna niejasność dotycząca jednostek oznacza, że prawodawca powinien unikać skomplikowanych semantycznie przepisów, utrudniając zrozumienie, a co za tym idzie — również prawidłowe zastosowanie normy prawnej. Obiektywna niejasność oznacza, że przepisy są niezrozumiałe na poziomie językowym nawet dla najlepszych znawców prawa ${ }^{32}$. Elementy formalne praworządności, na czele z zasadami dotyczącymi prawidłowej legislacji, są w istocie warunkami, które prawo ma spełnić, aby być prawem. Sama zasada legalizmu nie przesądza, że ustanowienie tekstu normatywnego w prawidłowej procedurze nadaje im przymiot prawa. Doktryna i praktyka w ciągu lat wypracowała liczne, wcześniej wymienione elementy, wchodzące w skład formalnego rozumienia praworządności, udowadniając, że nieprzestrzeganie ich szkodzi całemu systemowi prawa ${ }^{33}$.

27 K. Stępniak, Relacje między zasadami prawidłowej techniki prawodawczej a zasadami prawidtowej legislacji w procesie stanowienia prawa, „Przegląd Prawa Konstytucyjnego” 2017, nr 1 (35), s. 213-214.

28 T. Pietrzykowski, op. cit., s. 115.

29 Ibidem, s. 117.

30 J. Pietrzykowski, Wsteczne działanie prawa i jego zakaz, Kraków 2004, s. 54-55.

31 J. Pietrzykowski, Ujarzmianie Lewiatana..., s. 118.

32 Ibidem, s. 121.

33 T. Chauvin, op. cit., s. 13. 
Materialne rozumienie występowało w historii prawa już o wiele wcześniej, jednak jej elementy nie były utożsamiane z zasadą praworządności. Praworządność w tym rozumieniu opiera się na autorytecie prawa wraz z jego wpływem na społeczeństwo. W tej koncepcji wszyscy członkowie państwa, w tym i organy władzy publicznej, są równo traktowani i uważani za podlegających normom prawnym. Co ważne dla niniejszego wywodu — praworządność utożsamiana jest z sytuacją polityczną, a nie specyficzną regułą prawną ${ }^{34}$. Materialna definicja praworządności związana jest z zewnętrznymi wartościami prawa, spowodowanymi krytyką formalnej koncepcji rozumianej jako „oderwanej od społecznie aprobowanych wartości ugruntowanych w historycznych uwarunkowaniach, brak ścisłych związków z praktyką prawniczą i nieskuteczność polityki rozmijanej się z właściwymi celami państwa"35. Położenie nacisku na takie rozumienie praworządności powoduje, że jedynie prawo zgodne z wartościami danej społeczności, w której obowiązuje, jest de facto prawem ${ }^{36}$. Lech Morawski wskazał trzy różnice powodujące, że materialne rozumienie państwa prawnego jest czym innym niż formalne. W materialnym ujęciu źródła prawa to nie tylko teksty normatywne, ale także pewne reguły, które nie występują w nich, a derogacja prawa występuje nie tylko w wyniku formalnych procedur, dlatego przy spełnieniu pewnych przesłanek możliwe jest nieposłuszeństwo obywatelskie ${ }^{37}$.

Judykatura na skutek krytyki wyłącznie formalnego rozumienia praworządności wypracowała elementy, które są podstawą materialnej koncepcji, takie jak demokratyczny sposób stanowienia prawa, jawność procedury stanowienia prawa, zgodność prawa z systemem wartości społecznie aprobowanych, naród jako suweren, pluralizm polityczny ${ }^{38}$. Tak wypracowane elementy praworządności są warunkiem umożliwiającym zracjonalizowanie formalnej koncepcji. Tomasz Pietrzykowski, podając przykład Trzeciej Rzeszy — „można jednak wyobrazić sobie taki porządek prawny, który podobnie zbrodnicze praktyki realizowałby przy rzeczywistym zachowaniu wszelkich rygorów formalnie rozumianej praworządności" 39_ argumentuje, że stosowanie się wyłącznie do formalnej koncepcji powodowałoby, że w państwie zbrodniczym istnieje praworządność. Reasumując, katalog elementów praworządności występujący w materialnym rozumieniu może się zmieniać w zależności od wartości występujących na danym obszarze. Jednak, jak stwierdza Pietrzykowski, elementy te, mimo drobnych różnic, obejmują założenia oraz rozwiązania modelu państwa

34 B.A. Garner, Black's Law Dictionary, West 2009, s. 1448.

${ }^{35}$ R. Tokarczyk, Paradygmatyczne ujęcie koncepcyjnych i ustrojowych aspektów demokratycznego państwa prawa, [w:] Demokratyczne państwo prawa: zagadnienia wybrane, red. M. Aleksandrowicz, A. Jamróz, L. Jamróz, Białystok 2014, s. 141.

36 Ibidem, s. 142.

37 Ibidem.

38 Orzeczenie TK z dnia 8 maja 1990 roku, K 1/90, OTK 1990, nr 1, poz. 2.

39 T. Pietrzykowski, Ujarzmianie Lewiatana ..., s. 137. 
liberalno-demokratycznego ${ }^{40}$. Materialne rozumienie praworządności ma za zadanie ochronę wolności i praw człowieka ze szczególnym uwzględnieniem praw osobistych. Istotą nie jest trzymanie się litery prawa, lecz odzwierciedlanie określonych wartości, stanowiąc oraz stosując i interpretując prawo w zgodzie z nimi. Materialna koncepcja praworządności w korelacji z formalną najpełniej realizują ideę prawa, ponieważ zawiera nie tylko jego formę, ale także cele i funkcje. Właśnie te zasady związanie z obiema koncepcjami służą, jak stwierdza G. Palombella, ,zapobieżeniu przekształceniu prawa w narzędzie czystej dominacji, posłusznego sługę politycznego monopolu i instrumentalizmu"41.

Dekonstruując termin „praworządność”, uwidacznia się nam relacja między poszczególnymi elementami triady praworządności. Legalizm, mimo wchodzenia do wewnętrznych wartości prawa, należy potraktować osobno, ze względu na swoją charakterystykę oraz częste wyodrębnienie od innych elementów formalnych. Występowanie wyłącznie jednego albo dwóch elementów triady w rezultacie nie doprowadza do praworządności, lecz jedynie jej fikcji.

\section{Kultura prawna państw Europy Środkowo-Wschodniej i jej wpływ na prawo}

Kultura prawna to stosunek do prawa społeczności danego regionu, indywidualne oraz zbiorowe postawy wobec prawa do całego systemu prawa i poszczególnych norm ${ }^{42}$. W rozważaniach zostanie ujęta kultura prawna całej Europy Środkowo-Wschodniej, ze względu na podobieństwo kultur państw w tym okręgu. Odnosi się ona nie tylko do norm prawa stanowionego, ale także stosowania prawa przez organy i instytucje publiczne $e^{43}$.

Kultura oraz społeczeństwo Europy Środkowo-Wschodniej od dawna miały odmienne normy społeczne niż zachód kontynentu. Z odrębnością kulturową wiąże się również rozbieżność kultury prawnej ${ }^{44}$. Kultura Europy Środkowo-Wschodniej ujawnia następujące cechy: odrębność kulturowo-cywilizacyjna na skutek położenia geograficznego na pograniczu Europy; mieszanie się wartości rzymskokatolickich z prawosławnymi; ścieranie się wzorców i wartości zachodnioeuropejskich $\mathrm{z}$ orientalnymi; ukształtowanie specyficznego oblicza kulturowego, podatnego na

40 Ibidem, s. 138.

41 G. Palombella, The Rule of law as an institutional ideal, „Comparative Sociology” 9, 2010, nr 1, s. 4.

42 S. Grodziski, Z dziejów staropolskie kultury prawnej, Kraków 2004, s. 7-16.

43 J. Kurczewski, Prawem i lewem. Kultura prawna społeczeństwa polskiego po komunizmie, „Studia Socjologiczne” 2007, nr 2 (185), s. 34.

44 A. Chodubski, Europa Środkowo-Wschodnia wobec integracji i dezintegracji cywilizacyjnej świata, [w:] Na gruzach imperium... W stronę nowego ładu międzynarodowego i społeczno-politycznego w regionie Europy Środkowo-Środkowo-Wchodniej, red. A Stępień-Kuczyńska, M. Słowikowski, Łódź 2012, s. 13-34. 
zjawiska manipulacji ideologicznych i politycznych ${ }^{45}$. Oprócz kulturowych różnic, także wydarzenia historyczne, głównie druga połowa $\mathrm{XX}$ wieku, podczas której państwa Europy Środkowo-Wschodniej należały do bloku wschodniego, wpłynęły na kulturę prawną regionu. Przeszłość spowodowała, że społeczeństwa państw postkomunistycznych stały się oportunistyczne wobec prawa. Zmiany ustrojowe nie zlikwidowały negatywnego doświadczenia związanego z prawem ${ }^{46}$. Powstały liczne mity - negatywne i pozytywne - dotyczące praworządności, które utrzymują się w świadomości społeczeństw państw Europy Środkowo-Wschodniej ${ }^{47}$. Te negatywne przesądy stały się jednak dominujące w świadomości społeczeństw. Zaliczyć do nich możemy przedstawienia prawa jako narzędzia władzy, a także indywidualnych i grupowych potrzeb, grę politycznych interesów, celowe tworzenie niepotrzebnej biurokracji ${ }^{48}$. Dlatego kultura prawna państw postkomunistycznych opiera się na przeświadczeniach, które deprecjonują prawo jako wartość, ukazując jako narzędzie do utrzymania władzy i realizowania egoistycznych pobudek elity sprawującej władzę ${ }^{49}$.

Prawo jako wytwór kultury ludzkiej powstaje i zmienia się dzięki działaniu społeczeństwa. Prawo, jak uważa Eugen Ehrlich, jest żywe i ma trzy warstwy: zwyczajowo przyjęte zachowania, normy decyzyjne, służące rozwiązywaniu konfliktów, sformalizowane prawo państwowe ${ }^{50}$. Pierwsza warstwa, czyli zachowania zwyczajowo przyjęte, po pewnym czasie zostaje uregulowana przez ustawodawcę. Przechodzimy zatem z prawnie niewiążącej normy, występującej w konkretnym społeczeństwie, do normy generalno-abstrakcyjnej. Pochodzenie norm prawnych wywodzących się ze zwyczajowych, biorących się z kultury danego społeczeństwa, powoduje, że regulacje występujące $\mathrm{w}$ państwach będą odmienne $\mathrm{z}$ racji różnicy samej kultury. Naturalne są zatem różnice w regulacjach prawnych, wynikające z odmiennych zwyczajów i tradycji. Żeby prawidłowo zidentyfikować charakterystykę istniejącej kultury prawnej państw Europy Środkowo-Wschodniej, należy odnieść się do postkomunistycznych korzeni. Odmienność w prawie i jego stosowaniu w państwach Europy Środkowo-Wschodniej w drugiej połowie XX wieku była tak wyraźna, że John Henry Merryman podzielił tradycje prawne na trzy rodzaje: prawo kontynentalne, anglosaskie oraz socjalistyczne ${ }^{51}$. Po zmianach politycznych w Europie Środkowo-Wschodniej pod koniec XX wieku stało się

45 A. Chodubski, Europa Środkowo-Wschodnia jako przestrzeń pogranicza, „Studia Gdańskie. Wizje i rzeczywistość" 13, 2016, s. 229.

46 M. Kurkchyian, The Illgitimacy of Law in Post-Soviet Societes, [w:] Law and Informal Practices: The Post-Communist Experience, Oxford 2003, s. 26-27.

47 Ibidem, s. 28.

48 Ibidem, s. 28-29.

49 Ibidem, s. 45.

50 Z. Cywiński, Prawo żywe, [w:] Socjologia prawa, red. A. Kojder, Z. Cywiński, Warszawa 2014, s. 376-380.

51 J.H. Merryman, The Civil Law Tradition: An Introduction to the Legal System of Western Europe and Latin America, Stanford 1985, s. 1-4. 
to jeszcze bardziej widoczne. Istotną cechą charakterystyczną tejże kultury jest bardzo radykalne rozumienie prawa jako instrumentu, który ma służyć potrzebom ekonomicznym i polityce rządów państwa oraz interesom elit ${ }^{52}$. Pomimo zmian ustrojowych w państwach Europy Środkowo-Wschodniej zmiana kultury prawa nie nastąpiła w krótkim czasie; zamiast tego do dzisiaj widoczna jest świadomość prawa w społeczeństwie oraz praktyce prawodawczej, występująca jeszcze w kulturze prawa socjalistycznego, spowodowana wprowadzeniem przez komunistów kultury „antylegalizmu"53. Mimo integracji europejskiej widocznej w coraz większym ujednoliceniu i harmonizacji prawa wschodnia część Unii Europejskiej pomija aspekt wartości wyznawanych przez większość społeczeństw Wspólnoty. Przyczyną takiego stanu rzeczy jest zgoła odmienna od Europy Zachodniej trajektoria rozwoju społeczno-ekonomicznego. Czyste naśladowanie wzorców Europy Zachodniej nie przyczyniło się do nadgonienia gospodarki państw Europy Środkowo-Wschodniej wedle zachodnich standardów ${ }^{54}$. A. Czarnota zauważa, że na skutek niezbyt efektywnej transformacji ustrojowej pod względem rozwiązań instytucjonalnych okres około trzydziestu lat transformacji można streścić, używając kilku ogólnych pojęć, które są oderwane od swojej definicji — demokracja, praworządność, wolny rynek ${ }^{55}$. Zmiany systemowe były prowadzone z zastosowaniem samych ogólnych pojęć, bez chęci radykalnych zmian, za którymi stało społeczeństwo każdego z państw, biorąc pod uwagę ich niechęć do poprzedniego ustroju. Zauważalna jest tutaj cały czas występująca niechęć do prawa i jego przestrzegania, zwłaszcza w początkowym latach transformacji ${ }^{56}$.

Niezgodność w rozumieniu praworządności występuje w postaci materialnego rozumienia praworządności przez władzę, a wartościami uznawanymi przez społeczeństwa wschodnioeuropejskie. Społeczeństwa państw bloku wschodniego mają tendencję do wymagania od organów władzy rozbudowanego systemu opieki, zauważa to S. Nowak - „W socjalizmie system społeczny jako całość i wszystkie jego układy instytucjonalne są odpowiedzialne za dobrobyt i warunki życia ludzi. Ludzie chcieliby spodziewać się uważnej opiekuńczości od instytucji" ${ }^{57}$.

Problemem wciąż negatywnego nastawienia do praworządności są doświadczenia podczas zmian ustrojowych. Prawo było wyrazem woli politycznej, prawnicy natomiast pochodzili z poprzedniego systemu ustrojowego i nie wzbudzali zaufania w społeczeństwie. Od transformacji składane były liczne skargi dotyczą-

52 A. Uzelac, Survival of the third legal tradition?, „Supreme Court Law Review” 2010, s. $377-$ 378.

53 J. Kurczewski, op. cit., s. 35.

54 A. Czarnota, Rule of law as an outcome crisis, „Hague Journal of the Rule of Law” 2016, s. 315 .

55 Ibidem, s. 320.

56 J. Kurczewski, op. cit., s. 36.

57 S. Nowak, System wartości spoleczeństwa polskiego, „Studia Socjologiczne” 2011, nr 1 (200), s. 269. 
cefunkcjonowania instytucji państwowych, a zdaniem opinii publicznej sytuacja obecna jest jeszcze gorsza ${ }^{58}$. Powoduje to, że społeczeństwo widzi prawo i państwo w sposób czysto instrumentalny, ponieważ sama władza tworzy je i stosuje, realizując filozofię prawa socjalistycznego. Omijanie materialnej oraz formalnej istoty praworządności, opierając się wyłącznie na zasadzie legalizmu, jest bardzo wygodne dla rządów z zapędami autorytatywnymi oraz totalitarnymi.

Obserwując obecny kryzys, należy zauważyć, że wszystkie zmiany w prawie następowały w wyniku określonych procedur prawnych, stwarzając jednocześnie fikcję praworządności, gdyż nie miały one umocowania w wartościach wewnętrznych oraz zewnętrznych, które to prawo ma chronić. Widoczne zatem są tutaj korzenie rozumienia prawa z modelu socjalistycznego, czyli jako narzędzie służące władzy do kreowania rzeczywistości takiej, jakiej oczekują. Legalizm ma za zadanie zapewnienie legitymizacji organów państwowych do sprawowania władzy. Polski Trybunał Konstytucyjny już we wczesnej fazie swego istnienia zauważał aspekt materialny praworządności, analizując ją jako element demokratycznego państwa prawnego, utożsamiając go na równi z aspektem formalnym ${ }^{59}$. Inny wyrok Trybunału Konstytucyjnego w przeciwieństwie do poprzednich wyroków stwierdza:

nie jest demokratycznym państwem prawnym państwo, które nie realizuje idei sprawiedliwości, przynajmniej pojmowanej jako dążenie do zachowania równowagi w stosunkach społecznych i powstrzymywanie się od kreowania nieusprawiedliwionych, niepopartych obiektywnymi wymogami i kryteriami przywilejów dla wybranych grup obywateli ${ }^{60}$.

Zauważa to także J. Oniszczuk, stwierdzając, że rządy prawa są w związku z ideą sprawiedliwości ${ }^{61}$. Trybunał Konstytucyjny podczas transformacji ustrojowej zwracał często uwagę na aspekt materialny praworządności, jednakże robił to - zdaje się — wyłącznie instrumentalnie, gwoli potrzeby prowadzenia polityki otwartej na współpracę z państwami Europy Zachodniej. Podejście polskiego TK do definiowania praworządności po wejściu do Unii Europejskiej zmieniło się diametralnie. Najbardziej zauważalnym przykładem jest wyrok z dnia 4 listopada 2015 roku o sygnaturze K 1/14. Orzeczenie dotyczyło Otwartego Funduszu Emerytalnego. Trybunał Konstytucyjny w orzeczeniu niejasno argumentuje konstytucyjność ustawy, omijając przy tym właśnie analizę pod katem materialnego aspektu praworządności ${ }^{62}$. Jest to jeden z przykładów, że aspekt materialny praworządności także rozumiany jest jako narzędzie określonych przez władze celów i przywoływany jest on tylko, jeżeli jest zgodny z obecną polityką.

\footnotetext{
58 A. Czarnota, op. cit., s. 319.

59 Orzeczenie TK z dnia 8 maja 1990 roku, K 1/90, OTK 1990, nr 1, poz. 2.

60 Wyrok TK z dnia 12 kwietnia 2000 roku, K 8/98, Dz.U. z 2000 r. Nr 28, poz. 352.

61 J. Oniszczuk, Wspótczesne państwo w teorii i praktyce, Warszawa 2011, s. 248.

62 Orzeczenie TK z dnia 4 listopada 2015 roku K 1/14.
} 
Cechy kultur wschodnioeuropejskich, zwłaszcza podatność na manipulacje polityczne oraz wyznawanie wartości będących połączeniem religii katolickiej, prawosławnej, a także kultury orientalnej ${ }^{63}$, powodują, że elementy materialne praworządności, wypracowane głównie przez doktrynę państw Europy Zachodniej ze szczególnym uwzględnieniem kultury anglosaskiej, nie znajdują aprobaty wśród większości społeczeństwa wychowanego na odmiennych wartościach. Bliższe i o wiele bardziej zrozumiałe dla przeciętnego obywatela jest widzenie prawa jako instrumentu, które stosują oderwane elity liberalne, demobilizujące politycznie obywateli ${ }^{64}$. Praworządność jest zatem wtedy, kiedy wszystko jest zgodne z prawem. Jest to rozumienie praworządności w sposób błędny, utożsamiając ją wyłącznie z synonimem legalności.

Powszechnym przekonaniem jest, że to prawo kształtuje społeczeństwo; jednak oddziaływanie jest dwustronne ${ }^{65}$ — nie tylko na szczeblu samego społeczeństwa, ale szczególnie jego elit politycznych, co przenosi się na jakość stanowienia i stosowania prawa. „To, jakie jest prawo pozytywne, jaki ma kształt i charakter związane jest też z tym, jakie jest samo społeczeństwo" ${ }^{66}$. Nierozerwalny związek pomiędzy społeczeństwem i prawem doprowadza do pewnych wspólnych cech, jakie wykazują - ocenianie ich przez pryzmat siebie nawzajem ${ }^{67}$. Dlatego tak istotnym elementem potrzebnym do rozumienia danego systemu prawnego jest właśnie kultura prawna danej społeczności. Jest ona jednym z asumptów stanowienia i stosowania prawa w określonej filozofii.

\section{Formalne rozumienie praworządności w Polsce i na Węgrzech}

Praworządność nie jest przez rządy Polski oraz Węgier odrzucana; słowo to ma bardzo pozytywną konotację i łamanie jej nie sprzyja wygranej w wyborach. Racjonalne jest, że każda partia polityczna opowiada się za nią jednocześnie. Liczne zmiany prawa wprowadzone przez rząd PiS uargumentowane są przywróceniem zaufania do sądownictwa, skuteczniejszym łapaniem przestępców, stosowaniem prewencji negatywnej, doprowadzeniem do dobrobytu państwa ${ }^{68}$. Wstępuje tutaj próba połączenia rozumienia praworządności jako synonimu legalizmu, a także zewnętrznych wartości prawa. Prawo tworzy i stosuje się w sposób zrealizowa-

63 T. Stryjek, op. cit., s. 790.

64 A. Czarnota, Populistyczny konstytucjonalizm czy nowy konstytucjonalizm?, „Krytyka Prawa” 11, 2009, nr 1, s. 30.

65 T. Marzec, Wpływ „Przyspieszania czasu” na prawo. Prawo i kultura prawna w erze informacji, „Kultura i Wartości” 2013, nr 2 (6), s. 35.

66 Ibidem, s. 36.

${ }^{67}$ Ibidem, s. 43.

68 A. Łukasiewicz, Zmiany w prawie za rządów PiS: zmiana goni zmianę, https://www.rp.pl/ Sedziowie-i-sady/305179844-Zmiany-w-prawie-za-rzadow-PiS-zmiana-goni-zmiane.html (dostęp: 17.05.2016). 
nia „naszych” interesów w oderwaniu od skutków w skali makroekonomicznej oraz abstrakcyjnie rozumianej sprawiedliwości. Przedstawiają to badania CBOS, które ukazują liczne wymagania obywateli względem państwa. Ankietowani opowiedzieli się za szerokimi swobodami i wolnością, jednocześnie chcieli państwa opiekuńczego. Obywatele, kierując się własnymi przekonaniami i doświadczeniami, mają bardzo interwencjonistyczne wymagania wobec państwa, takie jak zapewnienie minimalnego dochodu czy zakwaterowania, darmowej służby zdrowia oraz natychmiastowej pomocy państwa w razie potrzeby ${ }^{69}$. Są to postulaty, które wymagają od państwa i prawa ochrony indywidualnych potrzeb oraz poczucia bezpieczeństwa, także ekonomicznego. Jarosław Kaczyński, komentując taki stan w Polsce, stwierdził że: „nie ma w Polsce równowagi społecznej. Prawo może być instrumentalizowane, ponieważ są ku temu warunki społeczne" ${ }^{\text {70 }}$. Pojmowanie prawa w sposób instrumentalny jest najbardziej charakterystyczne dla modelu prawa socjalistycznego, które opiera się na ochronie praw ustawowych, zwłaszcza proceduralnych, ze szczególnym uwzględnieniem podporządkowania jednostek organom państwowym ${ }^{71}$. Leon Petrażycki stwierdził, że wartości prawne i moralne powinny być autoteliczne, czyli niesłużące innym celom, oraz nie mogą być zależne od określonych sytuacji czy warunków ${ }^{72}$. Wynika z tego, że praworządności nie ma, jeżeli wartości, jakie prawo ma ochraniać, są rozumiane w sposób instrumentalny. Model państwa opierający się niejasno sformułowanej praworządności już od podstaw jest wadliwy i skazany na kryzys. Nie jest możliwe funkcjonowanie państwa praworządnego, które urzeczywistnia tylko legalizm oraz zewnętrzne wartości prawa. Myślenie opierające się jedynie na zasadzie legalizmu implikuje myślenie o charakterze dychotomicznym; dana sytuacja faktyczna jest legalna albo nie. Występuje interpretowanie każdej sytuacji faktycznej w kwestiach legalności.

Stosowanie zasady legalizmu w oderwaniu od wewnętrznych wartości prawa powoduje zjawisko nadregulacji, które przejawia się w nieumiejętnej deregulacji prawa $\mathrm{z}$ jednoczesnym stanowieniem norm bez głębszej refleksji ${ }^{73}$. Proces ten jest tak zaawansowany w państwach Europy Środkowo-Wschodniej, że występują sytuacje, w których bez podstawy prawnej nie można podjąć decyzji, ponieważ inna norma wymaga regulacji w danej sprawie ${ }^{74}$. Najcelniejszym określeniem tego

69 B. Roguska, Powinność państwa wobec obywatela i obywatela wobec państwa, https:// www.cbos.pl/SPISKOM.POL/2013/K_104_13.PDF (dostęp: 15.07.2013).

70 J. Kaczyński, Czy Polska jest państwem prawa?, https://pressje.pl/media/pressje_shop/article/article issue 7.pdf (dostęp: 1.02.2010).

71 I. Markovits, The Death of Socialist Law?, https://www.annualreviews.org/doi/10.1146/ annurev.lawsocsci.3.081806.112849 (dostęp: 1.12.2007).

72 J. Kaczyński, op. cit.

73 P. Trudnowski, Szaleństwo produkcji prawa trwa. 5 pomysłów jak je zatrzymać, https:// klubjagiellonski.pl/2017/07/27/szalenstwo-produkcji-prawa-trwa-5-pomyslow-jak-je-zatrzymac/ (dostęp: 27.07.2017).

74 J. Kaczyński, op. cit. 
stanu rzeczy jest słowo „imbosybilizm”, czyli niemożliwość działania ze względu na procedury prawne ${ }^{75}$. Prawo zakazuje stosowania innego prawa $\mathrm{z}$ powodu sprzeczności przepisów. Nadmiar regulacji doprowadza do przeciążenia sądów i organów administracji pracą. Liczne zmiany powodują, że urzędnicy państwowi muszą jednocześnie pracować na tekstach normatywnych, zgoła odmiennych, tylko ze względu na termin wszczęcia postępowania, co znacznie spowalnia pracę. Nadmiar regulacji doprowadza do występowania coraz liczniejszych spraw administracyjnych bądź sądowych, wymagając coraz większego wyedukowania w konkretnej dziedzinie urzędnika ${ }^{76}$ — zatem, na skutek wielości przepisów, kompetencje nabyte przez osoby sprawujące funkcje publiczne maleją, ponieważ potrzebna jest coraz bardziej wykwalifikowana i doświadczona kadra urzędników, aby poradzić sobie z narastającą barierą prawną ${ }^{77}$.

Okres bloku wschodniego i występująca w świadomości społecznej kultura prawa socjalistycznego doprowadziły do braku świadomości w społeczeństwie wewnętrznych wartości prawa. Legalizm i populizm są bardzo wygodne dla władzy. Urzeczywistniając wyłącznie zasadę legalizmu, ułatwia się instrumentalizację prawa. Stosując wyłącznie legalizm, można zalegalizować lub zdelegalizować niemalże wszystko, a stosowanie zewnętrznych wartości prawa polega na utożsamianiu interesów elity do woli społeczeństwa. Jest to zauważalne w postulatach PiS oraz Fidesz, które polegają na antyelitaryzmie, jak i antypluralizmie ${ }^{78}$. Wydaje się, że to rozumienie praworządności jako legalności sprzyja rozumieniu prawa wyłącznie jako narzędzia do kształtowania rzeczywistości. Dlatego można usłyszeć postulaty o prawie, które są absurdalne. Takim przykładem jest wypowiedź P. Szumlewicza - „Ustawą znieść ubóstwo"79 . Jest to bardzo prosty przykład, lecz nie jedyny pokazujący, że rozumienie prawa instrumentalnie wyłącznie wypacza jego istotę oraz prawdziwy sens. Bardziej całościowym spojrzeniem na tworzenie prawa jako lekarstwa na każdy problem jest statystyka, która ukazuje, że od lat występuje tendencja wzrostowa produkcji prawa w Polsce ${ }^{80}$. Jest to przykład na istnienie inflacji legislacyjnej. Nadmierne regulacje oraz stosowanie się tyl-

75 Ibidem.

76 O. Barańska-Małuszek, Zmiany w sprawności organizacji pracy sądów wynikają z braku pomystu, https:/www.rp.pl/Sady-i-prokuratura/306229974-Zmiany-w-sprawnosci-organizacji-pracy-sadow-wynikaja-z-braku-pomyslu-Olimpia-Baranska-Maluszek.html (dostęp: 22.06.2019).

77 P. Szymianiak, Nadmierne obciążenie sędziów. Resort sprawiedliwości jest otwarty na zmiany, https://prawo.gazetaprawna.pl/artykuly/1402260,sedziowie-dostana-wiecej-czasu-w-pracy.html (dostęp: 11.03.2019).

78 P. Kreko et al., Więcej niż populizm. Zjawisko trybalizmu na Wegrzech i Polsce, https:// www.politicalcapital.hu/pc-admin/source/documents/PC_BeyondPopulism_web_pl_20181018. pdf (dostęp: 18.10.2018).

79 J. Kozieł, Ustawa znieść ubóstwo, http://blog.jakubkoziel.pl/2014/03/ustawa-zniesc-ubostwo/ (dostęp: 8.03.2014).

80 https://barometrprawa.pl. 
ko do legalizmu z argumentacją ochrony dóbr i wartości są charakterystyczne właśnie dla państw z socjalistyczną kulturą prawną. Taka praktyka charakterystyczna jest dla państw o wielkich predyspozycjach do nagłych i częstych zmian społeczno-politycznych ${ }^{81}$. Zauważa to już Sąd Najwyższy w 2008 roku, komentując: „coraz bardziej rozbudowane i różnorodne, a jednocześnie zmienne, niejasne, pełne luk i wątpliwości oraz o niskiej jakości formalnej oraz merytorycznej”82.

Wspomniane wcześniej elementy kultury prawnej, takie jak wysokie wymagania obywateli względem państwa (oczekiwanie regulacji prawnej danej kwestii w celu rozwiązania bądź ułatwienia problemu), ułatwiają instrumentalizację prawa. Celem jest określone dobro będące aksjomatem, a prawo - narzędziem do realizacji. Poszczególne cele (takie jak sprawiedliwość) jednak nie muszą być bardzo abstrakcyjne; zamiast tego polegają na osiągnięciu określonej korzyści. Wysokie wymagania wobec państwa przejawiają się w roszczeniowości obywateli względem państwa o zapewnieniu pewnych dóbr. Nadmierność wymagań zachęca do stosowania przez władzę chwytów populistycznych, które licznymi obietnicami reform prawa starają się zachować elektorat. Taki stan rzeczy doprowadza do instrumentalizacji prawa, sprawiając, że w oczach elit sprawujących władzę, i społeczeństwa jest to tylko wytwór, który ma kreować rzeczywistość w dowolny sposób, marginalizując jego wartość.

\section{Podsumowanie}

Mnogość czynników, takich jak wydarzenia historyczne, cechy kulturowe danego społeczeństwa, bezrefleksyjne naśladowanie państw Europy Zachodniej, jak również sama integracja europejska doprowadziły do kryzysu praworządności. $\mathrm{Na}$ pytanie, czy istnieje praworządność w Polsce i Węgrzech, nie można prawidłowo odpowiedzieć pojedynczym stwierdzeniem. Instytucje unijne zauważyły problem, a w całej Europie pojawiła się żywa dyskusja na temat praworządności. Unia Europejska jako następca Wspólnoty Europejskiej wyznaje wartości będące jej fundamentem, a także wspiera integrację międzypaństwową. Polska oraz Węgry, przystępując do UE, musiały podporządkować się wartościom, które były celem jej powstania. Widoczne jest to zarówno w samej preambule, jak i artykule 2 Traktatu o Unii Europejskiej, a także w licznym orzecznictwie TSUE i dokumentach Rady Europy ${ }^{83}$, w których zawarte są oba aspekty praworządności: formalny i materialny. Dlatego o wiele wyraźniej widzą łamanie praworządności przez Polskę i Węgry państwa Europy Zachodniej, w których aspekt materialny kształto-

81 https://barometrprawa.pl/\#wykresy.

82 M. Domagalski, Sąd Najwyższy: pochwaty w gąszczu problemów, https://www.rp.pl/ artykul/320887-Sad-Najwyzszy--pochwaly-w-gaszczu-problemow.html (dostęp: 19.06.2009).

83 P. Bogdanowicz, Pojęcie i treść praworządności w prawie Unii Europejskiej, http:// robertgrzeszczak.bio.wpia.uw.edu.pl/files/2013/11/P-Bogdanowicz-Pojęcie-i-treść-praworządności. pdf (dostęp: 20.11.2013). 
wał się w nauce prawa wcześniej, a społeczeństwo wychowywało się w kulturze prawnej od lat przestrzegającej oraz rozwijającej prawa człowieka. Nieistnienie praworządności w państwie nie jest problemem dla elit sprawujących władzę. Wystarczy tylko sporządzić akt prawny i uchwalić go w zgodzie z procedurą.

Pojęcie praworządności rozwijało się i ewoluowało, mimo to fundament pozostał ten sam — ochrona jednostki. Obecny model przyjęty przez Polskę oraz Węgry zdaje się gubić ów pierwotny cel. Oprócz rozwiązań stricte instytucjonalnych, zaczynają wkraczać do kultury także odmienne wartości, które są podstawą systemów prawnych. Mechanizm ten powoduje, że w społeczeństwie dokonuje się polaryzacja; następują zwolennicy albo opozycjoniści obecnej władzy i jej kierunków politycznych. Ma to skutki nie tylko społeczne i polityczne, ale także poważne ekonomiczne, związane z licznymi wydatkami na ciągłe przystosowanie państwa do zmian w prawie. Spolaryzowane społeczeństwo łatwiej ulega manipulacji populizmu.

Warto podkreślić, że występuje także przeświadczenie, że prawo jest panaceum na każdy problem społeczny, polityczny, ekonomiczny. Liczba wciąż tworzących się tekstów normatywnych, które są niezgodne z praktyką tworzenia aktów prawnych, doprowadzają do utrudniania działalności sądów, władzy wykonawczej, jak i samej władzy ustawodawczej. ,Martwe prawo jest gorsze niż brak uregulowań prawnych"84 - trafnie zauważył M. Łuczak, mówiąc o Polsce, że „,w naszym kraju pokutuje magiczna wiara w moc prawa. Paragrafy mają odmieniać postępowanie ludzi, a nakazy i zakazy — zmienić rzeczywistość" 85 . Samo naśladowanie rozwiązań pochodzących z państw Europy Zachodniej bez wchłonięcia do swojego systemu elementów praworządności materialnej, określonych przez naukę zachodnią, nie spowoduje, że rządy prawa będą istnieć. Zamiast tego jest aberracją, tylko powierzchownie przypominającą praworządność. Fikcja wchłonięcia całej kultury prawnej Zachodu tylko pogarsza autorytet do tworzenia prawa w takiej filozofii. Takie prawo nie budzi autorytetu, tylko frustrację i szukanie ,luk w prawie" przez jednostki, aby dostosować do indywidualnych potrzeb. Jak wynika z badań CBOS opublikowanych w 2018 roku:

W porównaniu z poprzednim pomiarem z 2016 roku w największym stopniu obniżyła się wiarygodność Trybunału Konstytucyjnego, straciły także IPN i sądy. W dłuższej perspektywie ostatniej dekady, a więc paradoksalnie w czasach największych inwestycji dokonywanych z udziałem funduszy europejskich, obserwujemy spadek zaufania do UE. O pewnym kryzysie wiarygodności można mówić w przypadku tradycyjnych, przedinternetowych środków przekazu. W tym roku odnotowaliśmy najniższą $\mathrm{w}$ historii wiarygodność gazet i telewizji ocenianych ogólnie, bez różnicowania sympatii i orientacji politycznych ${ }^{86}$.

${ }^{84}$ M. Łuczak, Prawo do bezprawia, https://www.wprost.pl/tygodnik/31838/Prawo-do-bezprawia. html (dostęp: 17.11.2002).

85 Ibidem.

${ }^{86}$ A. Cybulska, K. Pankowski, O nieufności i zaufaniu, https://www.cbos.pl/SPISKOM. POL/2018/K_035_18.PDF (dostęp: 15.03.2018). 
Brak zaufania do prawa wiąże się z tym, że ludzie nie widzą wartości wynikającej z samego prawa, lecz jedynie narzędzie, które, jeżeli nie nadaje się do określonego celu, może być pominięte. Transplantacja prawa państw zachodnich bez odpowiedniej zmiany dostosowującej do warunków społeczno-ekonomicznych nie jest dobrym kierunkiem zmian ${ }^{87}$. Transplantowane prawo tworzone jest z uwagi na wartości zachodnioeuropejskie i nie może zostać przeniesione dosłownie, uwzględniając odmienną specyfikę kultury prawnej społeczeństw Europy Środkowo-Wschodniej. W Polsce i na Węgrzech występuje odmienny model prawa, pomimo licznych podobieństw do systemu prawa kontynentalnego, takich jak opieranie się na prawie stanowionym, spuścizna prawa rzymskiego, kodyfikacja prawa ${ }^{88}$. Sytuacja w Polsce i na Węgrzech doprowadza do refleksji związanej z zaufaniem do prawa. Stosowanie prawa wyłącznie instrumentalnie świadczy o pobudkach władzy do autorytatywnego modelu państwa. Rozwiązaniem mogącym zażegnać kryzys może być pogłębianie w społeczeństwie świadomości prawnej rozumianej jako wiedza oraz postawa jednostek wobec prawa ${ }^{89}$. „Zbyt duża liczba przepisów i brak dobrego systemu informacji powodują, że za zmianami nadąża niewielu Polaków" 90 . Stąd też możliwe poparcie partii rządzących pomimo łamania albo naginania zasad praworządności. Przez elity rządzące stosowany jest populizm, oparty na oczekiwaniach politycznych. Jedną z odpowiedzi na takie postępowanie jest zwiększenie świadomości prawnej, powstającej na skutek zwiększania poziomu społeczeństwa obywatelskiego, które samoorganizuje się, realizując cele bez pomocy rządu. Przykładem na to są demonstracje w obronie demokracji: marsze w Polsce, demonstracje antyrządowe na Węgrzech ${ }^{91}$. Kolejnym rozwiązaniem może być stworzenie w systemie prawnym pewnej strefy prawa, która będzie autonomiczna od działania państwa. Polegać ona będzie na samookreśleniu się w niej określonych grup społecznych z minimalną ingerencją państwa, podyktowaną ochroną bezpieczeństwa i porządku ${ }^{92}$. Takie rozwiązanie wyeliminuje oczekiwania wobec państw w niektórych sytuacjach oraz zmniejszy instrumentalizację prawa, ponieważ wymusi to od społeczeństwa traktowanie prawa jako wartość aniżeli instrument.

87 A. Watson, Legal Transplants:An Approach to Comparative Law, Edinburgh 1974, s. 21.

88 A. Korybski, L. Leszczyński, A. Pieniążek, Wstęp do prawoznawstwa, Lublin 2005, s. 59-60.

89 M. Borucka-Arctowa, Podstawowe problemy badań nad świadomościa prawna. Założenia badawcze, [w:] eadem, Świadomość prawna a planowe zmiany społeczne, Wrocław 1981, s. 5-6.

90 A. Łukasiewicz, Świadomość prawna Polaków — badanie Stowarzyszenia Sędziów Polskich Iustitia, https://www.rp.pl/Prawnicy/303089994-Swiadomosc-prawna-Polakow---badanie-Stowarzyszenia-Sedziow-Polskich-Iustitia.html (dostęp: 8.03.2013).

91 M. Strzałkowski, Wegry: Kolejne demonstracje przeciwko ,, ustawie niewolniczej”, https:// www.euractiv.pl/section/polityka-wewnetrzna-ue/news/wegry-kolejne-demonstracje-przeciwko-ustawie-niewolniczej/ (dostęp: 7.01.2019).

92 T. Marzec, op. cit., s. 43. 
Praworządność w Polsce i na Węgrzech nie jest rozumiana w sposób wypracowany od wieków przez doktrynę i teorię prawa. Najpoważniejszym problemem jest postawienie znaku równości pomiędzy praworządnością formalną a zasadą legalizmu. Powoduje to utratę wewnętrznych wartości prawa, które mają chronić pewność prawa i bezpieczeństwo względem niego, a także społeczeństwo przed absolutną władzą państwa ${ }^{93}$. Połączenie wyłącznie zasady legalizmu z materialnym aspektem praworządności jest niebezpieczny i prowadzi do populizmu, czego przykładem są wspomniane wydarzenia w Polsce i na Węgrzech. W państwie praworządnym muszą być przestrzegane zarówno wewnętrzne, jak i zewnętrzne wartości prawa. Kryzys jest zatem efektem historycznej spuścizny socjalistycznej kultury prawnej, odmiennych wartości w społeczeństwie, skutkujących wadliwie występującym w praktyce pojęciem praworządności.

Ujmując teoretycznie problematykę kryzysu praworządności, należy stwierdzić że występuje on, gdy brakuje w państwie jednego z elementów triady praworządności: legalizmu, wewnętrznych lub zewnętrznych wartości prawa. W rezultacie prowadzi to do wypaczenia istoty praworządności. Kryzys występujący w Polsce i na Węgrzech był spowodowany brakiem wewnętrznych wartości prawa z powodu wcześniej wspomnianej spuścizny historycznej i idącą z nią niską świadomością prawną społeczeństwa oraz złą techniką legislacyjną. Rozwiązaniem może być zwiększenie świadomości prawnej społeczeństwa poprzez lepszą edukację prawniczą oraz zaprzestanie traktowania prawa jako instrumentu do rozwiązywania każdego problemu występującego w państwie.

\section{Bibliografia}

Barańska-Małuszek O., Zmiany w sprawności organizacji pracy sądów wynikaja z braku pomystu, https://www.rp.pl/Sady-i-prokuratura/306229974-Zmiany-w-sprawnosci-organizacji-pracy-sadow-wynikaja-z-braku-pomyslu---Olimpia-Baranska-Maluszek.html.

https://barometrprawa.pl.

https://barometrprawa.pl/\#wykresy.

Bayer L., Orban reject EPP concerns on rule of law, https://www.politico.eu/article/viktor-orban-rejects-epp-concerns-rule-of-law/.

Bogdanowicz P., Pojęcie i treść praworządności w prawie Unii Europejskiej, http://robertgrzeszczak.bio.wpia.uw.edu.pl/files/2013/11/P-Bogdanowicz-Pojęcie-i-treść-praworządności.pdf.

Borucka-Arctowa M., Podstawowe problemy badań nad świadomościa prawną. Założenia badawcze, [w:] eadem, Świadomość prawna a planowe zmiany społeczne, Wrocław 1981.

Chauvin T., Przypadki króla Rexa - koncepcja wewnętrznej moralności prawa Lona Luvois Fulle$r a$, ,Edukacja Prawnicza” 2013, nr 4 (142).

Chełmiński J., Nie żyje Piotr S., który podpalit się pod Pałacem Kultury, https://warszawa.wyborcza.pl/warszawa/7,54420,22580825,nie-zyje-piotr-s-mezczyzna-ktory-podpalil-sie-pod-palacem.html.

Chojnicka K., Olszewski H., Historia doktryn politycznych i prawnych, Poznań 2004.

93 R. Tokarczyk, op. cit., s. 141.

Studenckie Prace Prawnicze, Administratywistyczne

i Ekonomiczne 31, 2020

(C) for this edition by CNS 
Chodubski A., Europa Środkowo-Wschodnia jako przestrzeń pogranicza, „Studia Gdańskie, Wizje i rzeczywistość" 13, 2016.

Chodubski A., Europa Środkowo-Wschodnia wobec integracji i dezintegracji cywilizacyjnej świata, [w:] Na gruzach imperium... W stronę nowego ładu międzynarodowego i społeczno-politycznego w regionie Europy Środkowo-Środkowo-Wchodniej, red. A Stępień-Kuczyńska, M. Słowikowski, Łódź 2012.

CybulskaA., Pankowski K., Onieufności izaufaniu, https://www.cbos.pl/SPISKOM.POL/2018/K_035_18. PDF.

Cywiński Z., Prawo żywe, [w:] Socjologia prawa, red. A. Kojder, Z. Cywiński, Warszawa 2014.

Czarnota A., Rule of law as an outcome crisis, „Hague Journal of the Rule of Law” 2016.

Czarnota A., Populistyczny konstytucjonalizm czy nowy konstytucjonalizm?, „Krytyka Prawa” 11, 2009, nr 1 .

Domagalski M., Sąd Najwyższy: pochwały w gaszczu problemów, https://www.rp.pl/artykul/320887-Sad-Najwyzszy--pochwaly-w-gaszczu-problemow.html.

Drabik P., Ile trwa założenie firmy? Ttumaczymy krok po kroku, https://biznes.radiozet.pl/Firma/Ile-trwa-zalozenie-firmy-2019.-Przez-internet.-Ile-trwa.-Gdzie-zlozyc-wniosek.

Fuller L.L., Moralność prawa, przeł. S. Amsterdamski, Warszawa 2004.

Garlicki L., Prawo konstytucyjne. Zarys wyktadu, Warszawa 2016.

Garner B.A., Black's Law Dictionary, West 2009.

Grodziski S., Z dziejów staropolskie kultury prawnej, Kraków 2004.

Integracja Europejska, https://encyklopedia.pwn.pl/haslo/integracja-europejska;3915015.html.

Kaczyński J., Czy Polska jest państwem prawa?, https://pressje.pl/media/pressje_shop/article/article_issue_7.pdf.

Kalisz A., Multicentryczność systemu prawa polskiego a działalność orzecznicza europejskiego trybunału sprawiedliwości i europejskiego trybunału praw czlowieka, „Ruch Prawniczy, Ekonomiczny i Socjologiczny" 69, 2007, z. 4.

Kaźmierczyk J., Nowak D., Czy kryzys węgierski można potraktować jako przykład kryzysu modelu gospodarki?, [w:] W poszukiwaniu nowego ładu ekonomicznego, red. A. Pollok, S. Owsiak, Warszawa 2013.

Kaźmierczyk S., [w:] Wprowadzenie do nauk prawnych. Leksykon tematyczny, red. A. Bator, Wrocław 2016.

Kelemen R.D., Europa nie powinna poddawać się w walce o praworząność, https://www.euractiv. $\mathrm{pl} /$ section/grupa-wyszehradzka/opinion/europa-nie-powinna-zaprzestac-walki-o-praworzadnosc/.

Kleiber M., Kleiber: Polaryzacja społeczna zagraża gospodarce i bezpieczeństwu państwa, https:// www.gazetaprawna.pl/artykuly/935034,kleiber-polaryzacja-spoleczna-zagraza-gospodarce-i-bezpieczenstwu-panstwa.html.

Korybski A., Leszczyński L., Pieniążek A., Wstęp do prawoznawstwa, Lublin 2005.

Kozieł J., Ustawa znieść ubóstwo, http://blog.jakubkoziel.pl/2014/03/ustawa-zniesc-ubostwo/.

Kreko P., Molnar C., Juhasz A., Kucharczyk J., Pazderski F., Więcej niż Populizm. Zjawisko trybalizmu na Wegrzech i Polsce, red. F. Rasmi, https://www.politicalcapital.hu/pc-admin/source/ documents/PC_BeyondPopulism_web_pl_20181018.pdf.

„kryzys demokracji”, https://trends.google.com/trends/explore?q=democracy\%20 crisis.

Kurczewski J., Prawem i lewem. Kultura prawna spoleczeństwa polskiego po komunizmie, „Studia Socjologiczne" 2007, nr 2 (185).

Kurkchyian M., The Illgitimacy of Law in Post-Soviet Societes, [w:] Law and Informal Practices: The Post-Communist Experience, Oxford 2003.

Leyland C., Old Words, new words, EU Words: Brexit and the OED, https://public.oed.com/blog/ brexit-and-the-oed/.

Studenckie Prace Prawnicze, Administratywistyczne

i Ekonomiczne 31, 2020

(C) for this edition by CNS 
Łuczak M., Prawo do bezprawia, https://www.wprost.pl/tygodnik/31838/Prawo-do-bezprawia.html.

Łukasiewicz A., Świadomość prawna Polaków - badanie Stowarzyszenia Sędziów Polskich Iustitia, https://www.rp.pl/Prawnicy/303089994-Swiadomosc-prawna-Polakow---badanie-Stowarzyszenia-Sedziow-Polskich-Iustitia.html.

Łukasiewicz A., Zmiany w prawie za rządów PiS: zmiana goni zmianę, https://www.rp.pl/Sedziowie-i-sady/305179844-Zmiany-w-prawie-za-rzadow-PiS-zmiana-goni-zmiane.html.

Markovits I., The Death of Socialist Law?, https://www.annualreviews.org/doi/10.1146/annurev. lawsocsci.3.081806.112849.

Marzec T., Wplyw „Przyspieszania czasu” na prawo. Prawo $i$ kultura prawna $w$ erze informacji, Kultura i Wartości 2013, nr 2 (6).

Merryman J.H., The Civil Law Tradition: An Introduction to the Legal System of Western Europe and Latin America, Stanford 1985.

Mierzyńska A., Polacy wcale nie chca Polexitu! Fatszywa sensacja po sondażu Eurobarometru, https://oko.press/polacy-wcale-nie-chca-polexitu-falszywa-sensacja-po-sondazu-eurobarometru/.

Morrow A., Hungary stages mass protest against new constitution, https://www.pri.org/stories/2012-01-03/hungary-stages-mass-protest-against-new-constitution.

Nowak S., System wartości społeczeństwa polskiego, „Studia Socjologiczne” 2011, nr 1 (200), Warszawa 2011.

Oniszczuk J., Współczesne państwo w teorii i praktyce, Warszawa 2011.

Palombella G., The rule of law as an institutional ideal, „Comparative Sociology” 9, 2010, nr 1.

Pietrzykowski T., Ujarzmianie Lewiatana. Szkice o idei rząów prawa, Katowice 2014.

Pietrzykowski T., Wsteczne działanie prawa i jego zakaz, Kraków 2004.

Raz J., Autorytet prawa, przeł. P. Maciejko, Warszawa 2001.

Roguska B., Powinność państwa wobec obywatela i obywatela wobec państwa, https://www.cbos. pl/SPISKOM.POL/2013/K_104_13.PDF.

Singer B., Operative Rights, Albany 1993.

Skokowska E., Kształtowanie się ducha absolutnego wedtug Georga Wilhelma Friedricha Hegla, https://ethnographerwrites.wordpress.com/2009/05/02/35/.

Sobolewski M., Koncepcja państwa prawnego (Rechtsstaat) $w$ doktrynie niemieckiego liberalizmu epoki klasycznej (do 1866 r.), PiP 1980, z. 2.

Stępniak K., Relacje między Zasadami Prawidłowej Techniki Prawodawczej a Zasadami Prawidtowej legislacji w procesie stanowienia prawa, „Przegląd Prawa Konstytucyjnego” 2017, nr 1 (35).

Stryjek T., Europa Środkowa (Środkowo-Wschodnia), czyli o pochwale różnorodności i komparatystyki, „Kwartalnik Historyczny” 120, 2013, nr 4.

Strzałkowski M., Wegry: Kolejne demonstracje przeciwko „ustawie niewolniczej”, https://www. euractiv.pl/section/polityka-wewnetrzna-ue/news/wegry-kolejne-demonstracje-przeciwko-ustawie-niewolniczej/.

Szymianiak P., Nadmierne obciażenie sędziów. Resort sprawiedliwości jest otwarty na zmiany, https://prawo.gazetaprawna.pl/artykuly/1402260,sedziowie-dostana-wiecej-czasu-w-pracy. html.

Ślubowski G., Wybory na Węrzech. Skąd wzią się sukces Viktora Orbana?, https://www.polskieradio.pl/7/1696/Artykul/2089448,Wybory-na-Wegrzech-Skad-wzial-sie-sukces-Viktora-Orbana.

Tokarczyk R., Paradygmatyczne ujęcie koncepcyjnych i ustrojowych aspektów demokratycznego państwa prawa, [w:] Demokratyczne państwo prawa: zagadnienia wybrane, red. M. Aleksandrowicz, A. Jamróz, L. Jamróz, Białystok 2014.

Tomasz z Akwinu, Suma teologiczna, przeł. F. Bednarkiewicz, S. Bełch, A. Głażewski, t. 13, Kęty 2010, t. XIII.

Studenckie Prace Prawnicze, Administratywistyczne

i Ekonomiczne 31, 2020

(C) for this edition by CNS 
Trudnowski P., Szaleństwo produkcji prawa trwa. 5 pomystów jak je zatrzymać, https://klubjagiellonski.pl/2017/07/27/szalenstwo-produkcji-prawa-trwa-5-pomyslow-jak-je-zatrzymac/.

Uhlig D., Kubik A., Wilgocki M., Licznik tyka: juz dwa lata bez publikacji wyroku Trybunału Konstytucyjnego, http://sonar.wyborcza.pl/sonar/7,156422,23120979,dwa-lata-bez-publikacji-wyroku-tk-licznik.html.

Uzelac A., Survival of the third legal tradition?, „Supreme Court Law Review” 2010.

Watson A., Legal Transplants:An Approach to Comparative Law, Edinburgh 1974.

Wszystkie protesty na jednej mapie. W obronie sądów spotkaliśmy się w ponad 250 miastach, http://biqdata.wyborcza.pl/biqdata/7,159116,22176137,wszystkie-protesty-na-jednej-mapie-w-obronie-sadow-spotkalismy.html.

Zajadło J., Marksistowska teoria prawa, [w:] Leksykon wspótczesnej teorii i filozofii prawa, red. J. Zajadło, Warszawa 2007. 